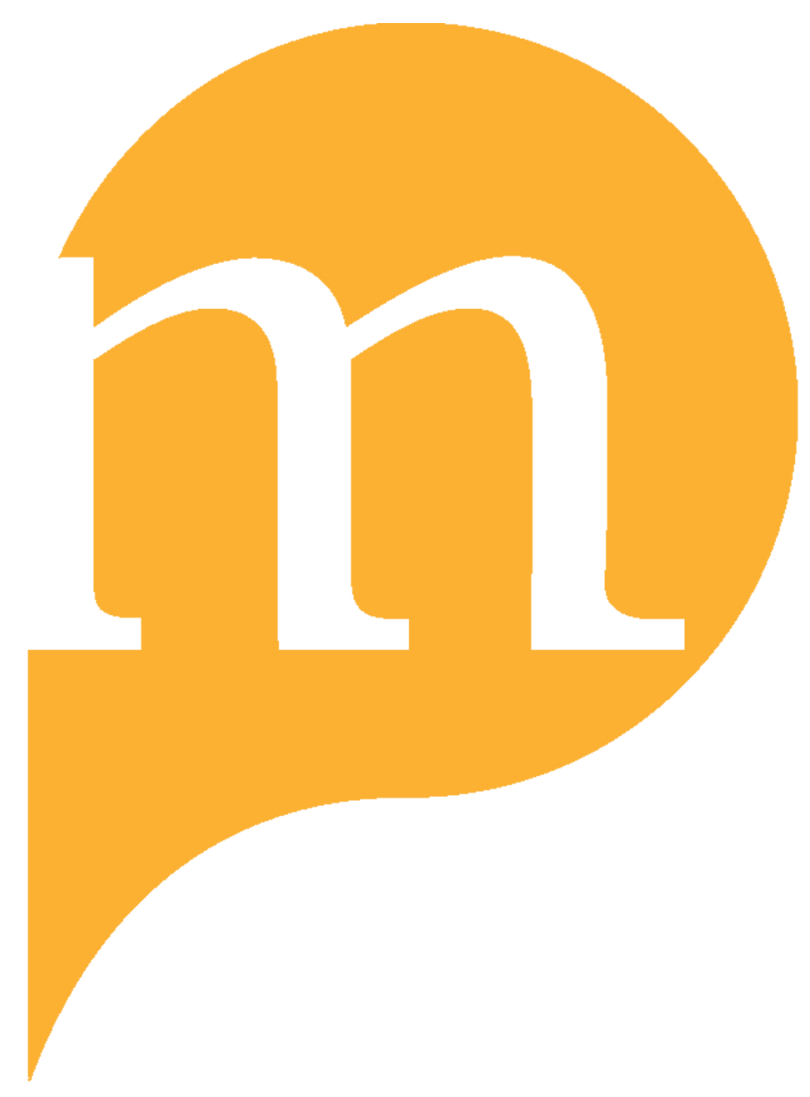

PROJECT MUSE 


\section{JEAN-PIERRE BEKOLO'S AFRICAN CYBORGIAN THOUGHT}

\section{Matthew Omelsky}

I n his essay "Welcome to Applied Fiction," the filmmaker Jean-Pierre Bekolo presents a cosmic vision of our contemporary world. Digital technology and machines are so ubiquitous in his envisioned topography that they become invisible. The organic world, the body, and all electronic devices become interconnected media through their integration into an "Internetized" global circuit. Microwaves, computers, and cell phones become vehicles for knowledge production and dissemination. Humans take on a "new anatomy" - their legs are wheels, their eyes cameras. Society's ancient myths must be rewritten in this new landscape, creating new narratives that provoke critical awareness and political transformation. The boundary separating the real and the imaginary must dissolve. And immortality, or the continuation of "the energy of life," must be our ultimate a mbition. Bekolo's vision is a quest for liberation, and our role as inhabitants of this space, he says, is "entirely political."

These postmodernist thoughts and their integration into Bekolo's films are not without their artistic and intellectual precursors. His films evoke the avant-garde films of the late Djibril Diop Mambéty of Senegal, whose Touki bouki (1973) and Hyènes (1992) depict fragmented worlds through experimental narrative and cinematic techniques. Slowmotion sequences, abrupt cutaways, and sometimes shocking image juxtapositions elicit multiple readings in Bekolo and Mambéty's works. ${ }^{2}$ Bekolo's "new anatomy" and his call for new modes of thought also seem to echo the resounding final line in Frantz Fanon's Wretched of the Earth: "We must ... develop a new way of thinking, and endeavor to create a new man." Just as Fanon calls for the (de)colonized to reinvent themselves, Bekolo calls for the inscription of new thought, new notions of embodiment, and new myths.

While Fanon's primary subjects are those who are newly decolonized and emerging from revolutionary struggle, Bekolo's principal subjects are African youth. Bekolo sees a dire need to engage the ways in which youth imagine, anticipate, and shape the world around them. The filmmaker's commitment to youth is clear in his feature films (Quartier Mozart, Aristotle's Plot, Les saignantes), all of which integrate youth culture in both their cinematic form and their content. ${ }^{4}$ His protagonists and themes 


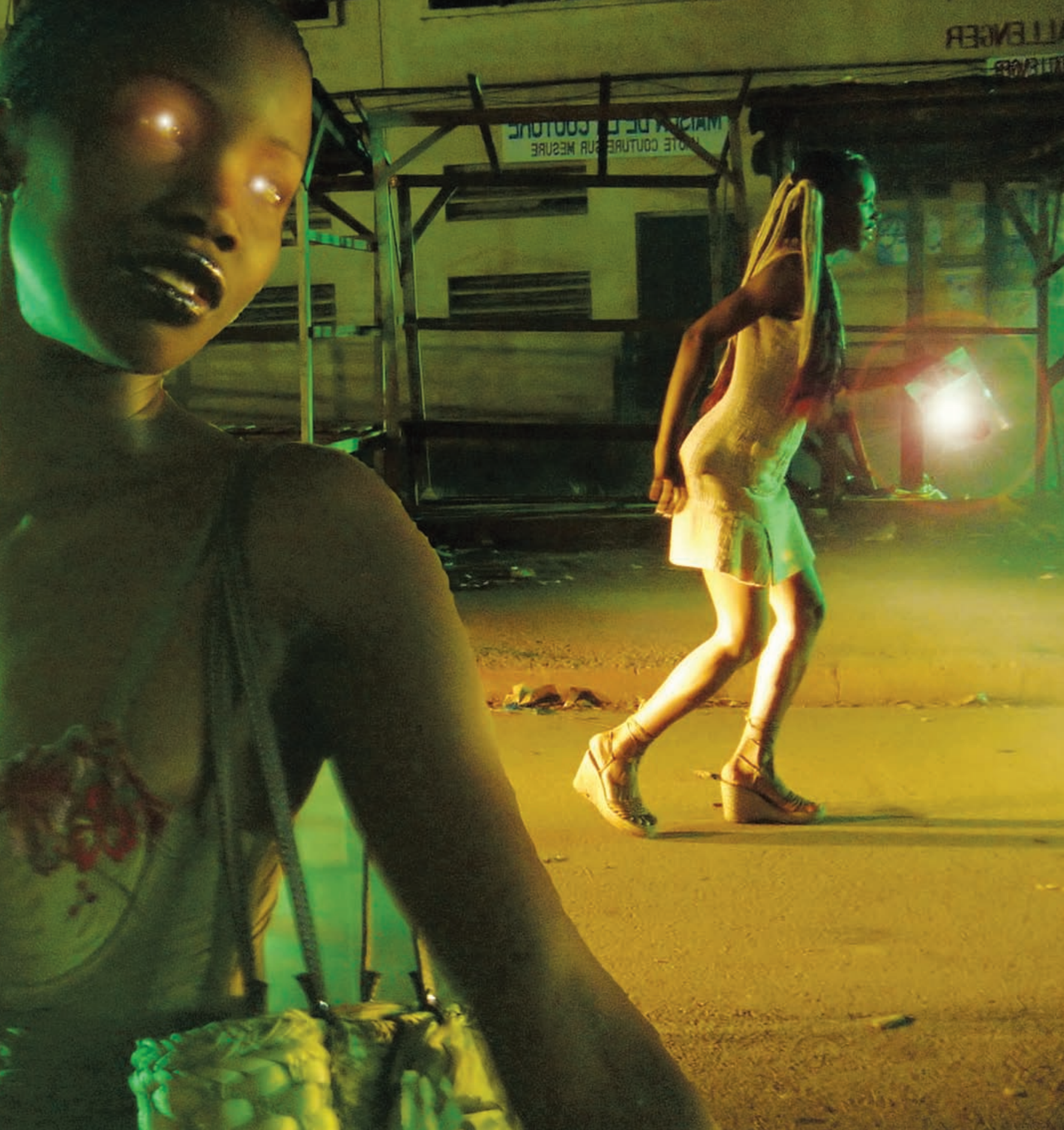

Jean-Pierre Bekolo, Les saignantes, 2005. Film still, Adèle Ado as Majolie (left) and Dorylia Calmel as Chouchou (right)

come straight out of the contemporary youth experience, as does his filmic style, which often incorporates music video-like sequences. Through film Bekolo seeks to show youth his vision of society's new anatomy and to urge them to challenge dominant modes of thought.

In recent years Bekolo's sustained engagement with youth has resembled what might be called an "African cyborgian thought." His essay "Welcome to Applied Fiction" (2009) and his feature film Les saignantes (2006) have much in common with Donna Haraway's iconic politics of the cyborg, yet Bekolo articulates a distinct reconfiguration of the cyborg for African spaces. Central to Har- 


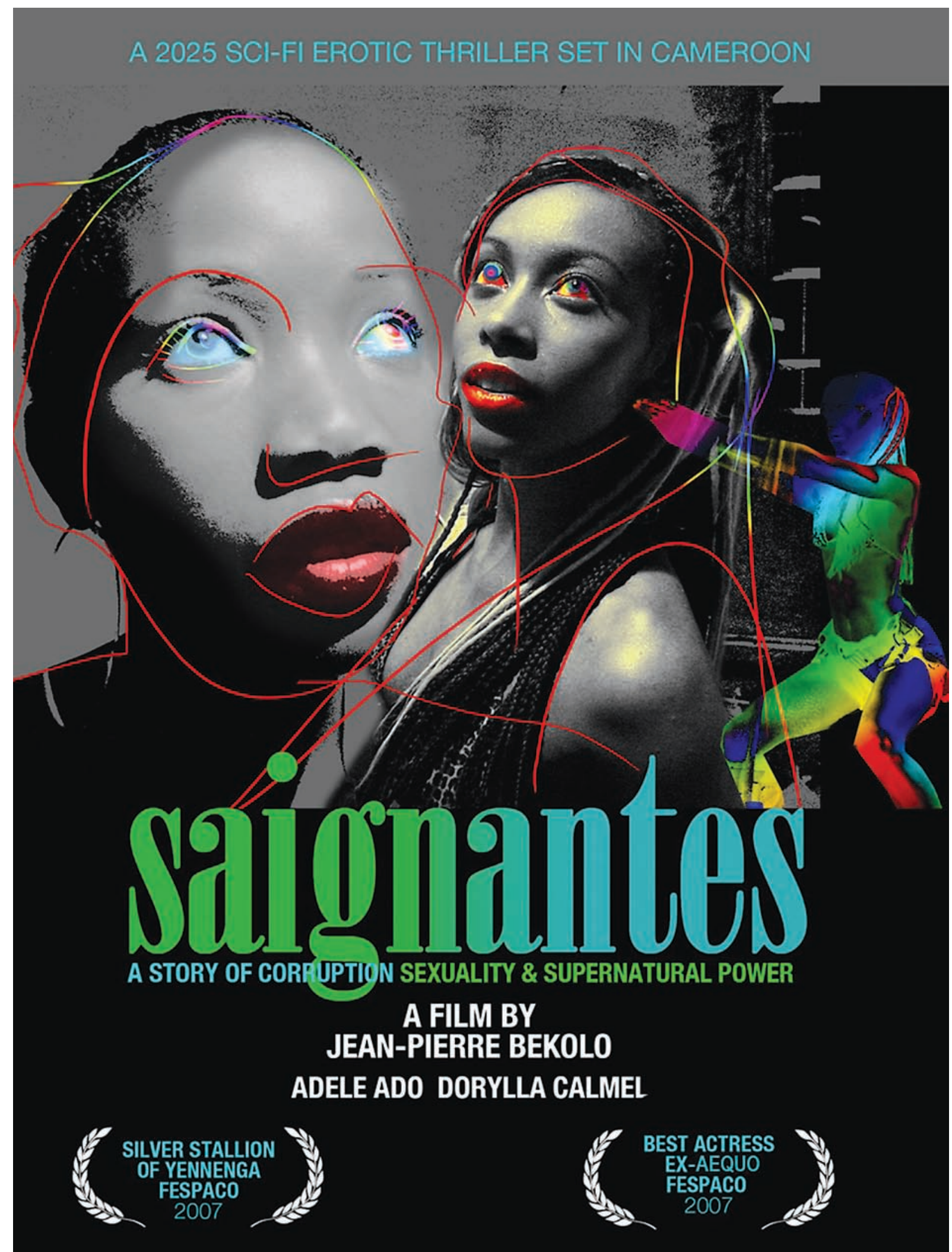

Poster for Les saignantes, 2006. Courtesy the filmmaker 
away's thought and Bekolo's recent artistic vision is the notion that rigid dualisms such as "organism/ machine," "fiction/lived experience," and "primitive/civilized" only reinforce the "logics and practices of domination" that have designated so many global groups as other (e.g., women, people of color, the poor). Haraway and Bekolo set out to break down these hegemonic dualisms; they look to subvert and recast society's central myths of origin and narratives of wholeness; they envision a world in which ubiquitous technology and machines are deployed by their oppositional subjects. In their works women are the radical cyborgian subjects who undermine organic notions of femininity, the female body, and masculinist power structures. For Haraway and Bekolo alike, the cyborg myth is "resolutely committed to partiality, irony, intimacy and perversity. It is oppositional, utopian and completely without innocence." 5

Focusing on Les saignantes, this essay elucidates how Bekolo rearticulates cyborgian thought in an effort to remap dominant modes of social consciousness among African youth. In the film Bekolo uproots hegemonic tropes of African pathology; recasts narratives of African tradition in a way that forecloses singular, fixed interpretations; and depicts two young women who illustrate the potential for body and machine to merge in opposition to masculinist state power. Bekolo combines the oppositional postmodern thought of the cyborg with critical issues of gender, corruption, and tradition pertinent to present-day Africa. He breaks down dualisms such as "traditional/modern" and "developed/ underdeveloped" and calls into question the grand narratives and myths that purportedly structure African societies as well as the continent's global image. These questionings, subversions, and oppositional thoughts are directed primarily at African youth. Bekolo wants them to question their world, to dare to reimagine the spaces they inhabit.

Bekolo's provocative vision for African young people is multivalent. One possible reading is the more literal, and perhaps banal, lens of direct social application: Bekolo could be calling for youth to pour into the streets of Yaoundé and oust Cameroon's dictatorial regime (as if in anticipation of the "Arab Spring" revolutions in Tunisia and Egypt). Indeed, it would not be far-fetched to understand
Les saignantes as a plea for a humanistic notion of social action. Read through this literal lens, as it were, his liberatory rhetoric of changing reality and freeing ourselves reveals a sort of headstrong idealism, difficult as it may be to envision his "liberation" as a politically viable program on the ground.

However, this call for liberation and transformation is juxtaposed with Bekolo's "new anatomy," "reinvented grammar," and omnipresent technology. His ideas, ranging from myth and liberation to immortality and machines, seem to carry far more resonance on the level of thought and discourse than on the level of politics as a concrete praxis. Furthermore, Bekolo's vision does not so much call for a specific (re)formulation of thought as it urges youth to be critical of the social, political, and even cultural thought that surrounds them. His cyborgian vision is an imagined liberation in which the act of (re)imagining is itself a political act - an instance of social action. This politics of resistance operates best as a discursive critique of society and social thought.

Bekolo's cyborgian thought is, in a way, a radical expansion of Ngugi wa Thiong'o's notion of the "decolonized mind." ${ }^{\circ}$ Rather than offer a narrow critique of Europe's colonization of the African psyche, Bekolo seeks to subvert all hegemonic forms of thought and discourse, whether they originate in America, Europe, or the postcolony itself. For this filmmaker, no perspective can remain uninterrogated in our current historical moment. With his cyborgian rearticulations, Bekolo sets out to challenge dominant modes of social consciousness among contemporary African youth, pushing them to question and reshape the thought that directs their lives.

\section{Hyperbole and Pathology}

In Les saignantes Bekolo's cyborgian thought is most conspicuous in his hyperbolic depictions of African pathology. Instead of merely denouncing negative African stereotypes of corrupt officials or dystopian poverty, Bekolo amplifies these and other tropes to provoke critical engagement. Through his deliberately hyperbolic depictions of bleak landscapes and even cannibalism, for instance, Bekolo undermines the ideology behind these negative tropes and calls on viewers to actively interrogate their veracity and 


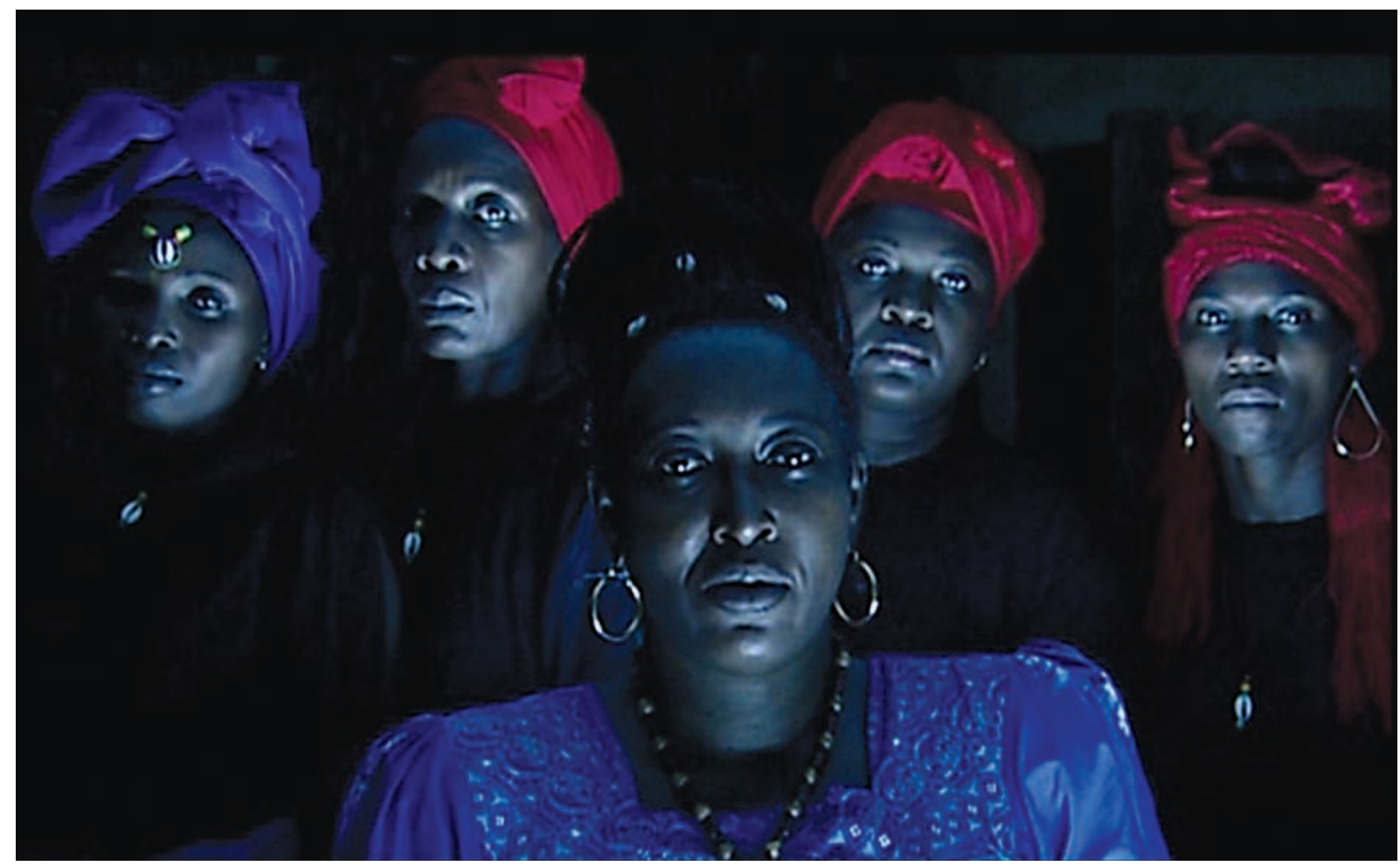

Les saignantes, 2006. Film still. Courtesy the filmmaker

societal function. Hyperbole is one way in which the filmmaker's cyborgian approach seeks to disrupt the grand narratives that structure African societies and the continent's global image.

At the forefront of Les saignantes is the trope of darkness. While his discursive use of the concept can be read in several ways, Bekolo foregrounds a literal darkness by setting the entire film under the cover of night. Ultradim green and blue lighting as well as ubiquitous smoke in most street scenes accompany this ominous physical darkness. Bekolo's sustained noir aesthetic establishes a bleak but ambivalent aura that is further complicated by the film's opening voice-over narration, which explains that "a darkness had fallen over society." The presence of a literal darkness seems clear, but the narration implies that society has also been enveloped by a sort of social darkness and lacks any clarity of thought.

Notions of darkness and impenetrability, of course, have a long and convoluted legacy vis-àvis the African continent. Perhaps the most iconic example is Joseph Conrad's Heart of Darkness (1902), which complicates the term with regard to the colonial encounter and affords multiple ambiguous readings, both literal and metaphorical. Indeed, in Conrad's novel the multivalent trope of darkness is simultaneously situated in the "primitive" Africans, colonialism itself, and perhaps even the reader. However, beyond this Conradian discursive ambivalence, the dominant strand of thought throughout the nineteenth and twentieth centuries was the attribution of darkness to the people of the "Dark Continent" and, in turn, the rationalization of Europe's violent colonial programs.

Bekolo is no doubt aware of the intellectual history of the term. His discursive use of the darkness trope not only brings this lineage to the front of the viewer's consciousness but also seems to try to provoke viewers to take a new critical approach. What might constitute darkness in contemporary Africa? Does the "West" solely construct this trope, or is there a certain African complicity in the constitution of today's darkness? Who, if anyone, benefits from this discursive allegation of abjection, and how might the term be manipulated to challenge the hegemony of these purported beneficiaries? With his hyperbolic noir aesthetics and rhetoric of 
"falling into darkness," Bekolo reifies the contaminated grand narrative of darkness to instigate a new critique. His exaggerated representations do not so much perpetuate the discursive violence of the term as they challenge viewers to rework and redeploy the term as a vehicle through which to critique their social and political positions.

Another series of tropes that Bekolo accentuates is the juxtaposition of an extravagant (government) elite with a dystopian urban landscape. The government officials on one side of this juxtaposition, men with insatiable appetites for sex, money, and power, are so stereotypical as to resemble caricatures. They flaunt their wealth through their brand-new European cars and expensive suits; their pursuit of women is constant. One official, the minister of state, has a women's underwear fetish that hampers his ability to run state affairs; another, the secrétaire général du cabinet civil (SGCC), dies while in bed with a young female prostitute in the film's opening sequence. ${ }^{7}$ Bekolo seems to create his depictions of government officials by drawing from tropes of lascivious, extravagant, and hypermasculine African leaders.

Bekolo contrasts this extravagance with ubiquitous material dilapidation. Crumbling buildings, abandoned construction sites, and deserted public facilities fill out the landscape as the officials cruise around in their hedonistic luxury. This contrast is particularly acute with regard to two vehicles, one owned by a taxi driver eking out a living and the other by the SGCC. The former is a mid-twentiethcentury Volkswagen Beetle. Since the film takes place in 2025, this car is likely close to fifty years old; it barely stays in one piece as it bumps along the pothole-ridden streets. The latter is the latest-model Mercedes Benz. It has a leather interior and tinted automatic windows and is operated by voice command. When the two prostitutes get into the car, a female voice says in English, "Greetings, I'm the artificial intelligence who will be assisting you." The juxtaposition of these two vehicles is but a microcosmic instance of a broader series of stereotypes that Bekolo evokes.

Bekolo does not simply perpetuate the negative African tropes of an extravagant elite and a dilapidated urban landscape; he amplifies them to critique their presuppositions and transform them into absurdities. Actual global stereotypes of corrupt African leaders who siphon billions of state dollars into personal Swiss bank accounts and images of extreme poverty and decrepitude among most Africans are what Bekolo relies on to support his critique. By presenting these globally circulating tropes hyperbolically, Bekolo urges viewers not to simply take them at face value. Hyperbole provokes questions concerning the tropes' actual veracity who creates them and who has a vested interest in perpetuating them. Bekolo's exaggerations undercut these narratives that threaten to shape the domestic and global images of the continent. His critique is meant both to facilitate broader critiques of those who spin these African narratives and to facilitate interrogations of the tropes' discursive underpinnings.

As part of Bekolo's cyborgian critical approach, these exaggerated tropes of African darkness, corrupt government officials, and impoverished landscapes are used to dismantle such grand narratives. They function as ideologies or modes of thought that play a critical role in the construction of hegemonic social structures both inside and outside African societies. In other words, such stereotypes have the potential to become naturalized, in the Gramscian sense of "commonsense thought," and subsequently reinforce positions of subordination and domination both domestically and transnationally. Like commonsense thought, these African tropes are often discursively employed without a sound consciousness of historicity or self-awareness. ${ }^{8}$ It is this consciousness and awareness that Bekolo attempts to instill in his audiences, particularly youth. To him, African youth in particular must become critically aware of these inherently disjointed and contradictory stereotypes that circulate globally, including the naturalized narratives of Africa's darkness and its lascivious political leaders. Young people must engage the historicity and construction of these tropes and recognize their hegemonic operation in the postcolony and in global discourse. Similarly, Bekolo's call for critical awareness extends to African tradition and myth: even the narratives that are purportedly organic to African societies must be radically reshaped in the cyborg world. 


\section{Tradition, Remixed}

In her "Cyborg Manifesto," Haraway explains that "cyborg politics is . . the struggle against perfect communication, against one code that translates all meaning perfectly." Cyborg politics embraces notions of "noise," "inauthenticity," and "queerness" that transform monolithic utterances into polyvalent intellectual maps. To think in a cyborgian way is to think through the possibility of new modes of thought - to reconstruct the narratives we have always known and open ourselves to that which we have never known. This refusal of singular meaning and commitment to opacity defines Bekolo's cyborgian take on African tradition. In his postmodern rearticulations of mevungu - the ancient tradition of female empowerment among the Beti of Cameroon-Bekolo provides an instance in which society's central myths and organic cultural lineages are stripped of their constricted meanings and integrated into this new circuit. Bekolo is a cyborgian DJ who samples bits and fragments of mevungu, pasting them onto his postmodern palette of electronic technologies and new anatomies. He reshapes mevungu into an ambivalent force, released from its rigidly singular significance.

Before unpacking Bekolo's samplings and rearticulations of mevungu, it is critical to address mevungu's singularity and its "traditional" significance in Cameroonian society. Although Bekolo himself is a member of the Beti ethnic group, he first learned of mevungu from the work of the French anthropologist Philippe Laburthe-Tolra, in whose ethnographic account we can situate mevungu's conventional meaning and position in society. ${ }^{10}$ In one of his tomes on the Beti, Initiations et sociétés secrètes au Cameroun, Laburthe-Tolra describes mevungu as a ritual of female empowerment and fecundity through which society combats evil forces (maléfices) that have caused misfortune (e.g., paltry harvest) in the community. In this female-only ceremony, the initiated women spend an entire night dancing, singing, and eating; they drink a slimy herbal liquid and burn a ceremonial phallic-shaped termite mound. Led by the "mother of mevungu," the women perform these rites and declare: "Toute personne qui te voudra du mal périra [All those who wish evil on you will perish]." The ancient rite centers on the power and fertility of the female body, particularly the clitoris; the mother of mevungu is said to posses the "grand clitoris." The female body projects its fertility and prosperity onto society at large by condemning those individuals who have willed evil on the community or have done evil. Once the condemned have either publicly confessed their malfeasance or "perished," the community enjoys a period of prosperity. In its "traditional" societal role, mevungu exposes the culpable and restores society's fruitfulness. ${ }^{11}$

Bekolo's depiction of mevungu in Les saignantes is far from an exact transcription of LaburtheTolra's account. He does not re-create a grand secret ceremony; instead, he implicitly cites mevungu conventions throughout the narrative, often in impromptu situations. These citations destabilize the fixed meaning and function of the mevungu rite. His intimations of mevungu effectively allow for it to be integrated into the protagonists' cyborgian world, facilitating its transformation into an indeterminate force. Consider, for instance, the film's reference to the clitoris. The protagonists, Majolie and Chouchou, playfully recite a song with call-andresponse lyrics: " - They want to see your clit. - No, not my clit, clit.” This clitoris reference clearly cites mevungu, but there is no direct mention of the rite in this scene; it is only intimated, and as a result any effort to discern a specific meaning is thwarted.

In a later scene with a similar sense of indeterminacy, Chouchou's mother forces Majolie to drink a slimy liquid while Majolie and Chouchou take a meal. The mother slowly and silently walks over to Majolie carrying a two-foot-tall martini glass filled with green slime. As Majolie cringes, her eyes bulging, the mother forces her head back and makes her drink the liquid, as if it is some sort of medicinal substance. Chouchou's mother appears to function as a sort of mother of mevungu both when she administers this green liquid and when she appears repeatedly on Chouchou's mobile video phone along with several severe-looking women, saying, "They want to see you." This statement and the forced slime consumption dangle enigmatically in the discursive economy of these scenes, yet both appear to be rough citations of mevungu female practices. Like Bekolo's ambiguous reference to the clitoris, these mevungu citations reaffirm his insistence on opacity and his resistance to fixed meaning. 


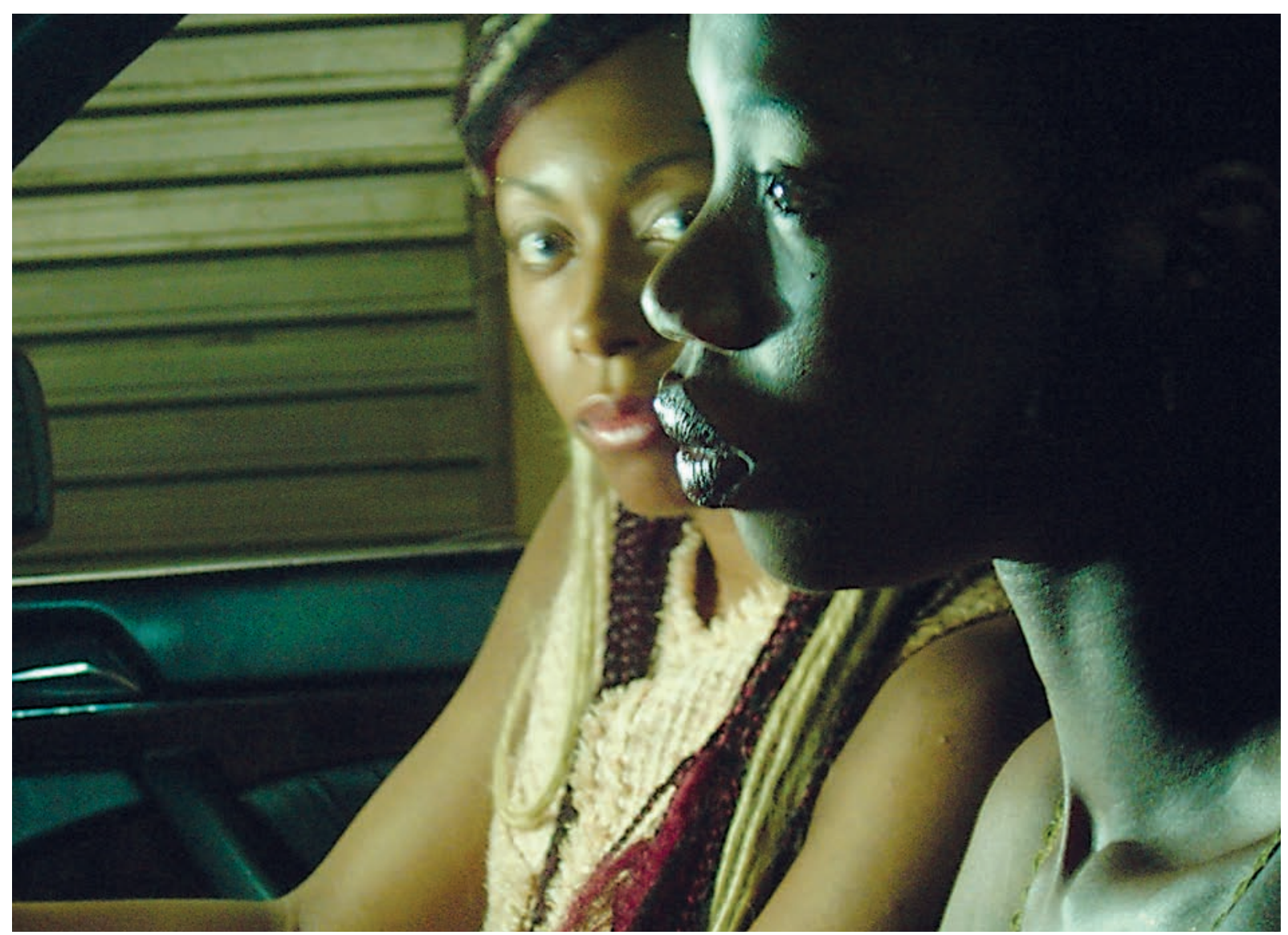

Les saignantes, 2006. Film still. Courtesy the filmmaker

By merging Chouchou's mother and her eerie women with ubiquitous video technology, Bekolo effectively inscribes the ancient Beti practice into his cyborgian landscape. He does not re-create the "organic" or "authentic" tradition; instead, he samples and cites this ancient rite, giving it a new shape to fit his new world and new anatomy. Bekolo's patchwork cyborgian mevungu is all about polyvalent meanings, ambivalence, and contingency, and he pushes these further with his use of abrupt cutaways, slow-motion sequences, and repetitive electronic music.

Along with these techniques of disorientation and citation, Bekolo also articulates his cyborgian mevungu through language, specifically through the film's voice-over narration. The term mevungu and all direct references to the ritual are uttered only by this omniscient low-pitched female voice. Just after the opening credits roll, with the camera fixated on a luminous full moon in a pitch-black sky, the nar- rator introduces mevungu with these deliberately opaque words: "Mevungu is neither a living being, nor an object. Mevungu is not a place, much less a moment. Mevungu is not a desire, above all not a state of mind [état], because mevungu is something that one sees, that one lives, without being able to define it. One doesn't decide to see mevungu. Mevungu appears to you. Mevungu invites itself." This introduction tells us not so much what mevungu is as what it is not. It articulates mevungu by proclaiming its inarticulability. The narrator maintains this tone throughout the film, leaving the viewer to guess at mevungu's ontology. But despite this obfuscation of meaning, Bekolo's cyborgian mevungu plays an integral role in nearly every scene.

Mevungu never ceases to be an ambivalent force in the film, but its very ambivalence is always articulated with discursive precision. In other words, the narrator's language appears to be painstakingly chosen, yet mevungu always seems to be associated 
with a sort of epistemological equivocation. As a result of this paradoxical coupling of precise language and imprecise significance, mevungu comes across as a contradictory force that simultaneously impedes and instigates social action. Indeed, the cyborgian mevungu operates both as the structure that constrains social actors and as a principal source of their agency. The SGCC's death at the beginning of the film prompts the narrator to reveal that mevungu "had fallen on us like a nightmare," sonalities). Death has become a celebrity affair, with feasts, sex, and extravagant displays of wealth. This situation is attributed to mevungu: "We lived in a time when wakes were the only parties people could celebrate," the narrator explains. "It was around mevungu that the society of tomorrow was being built. Everyone in this country invaded [investir] the funeral parlors. ... With mevungu, there was no questioning of these practices." The implication here is that the supernatural force operates as a sort of

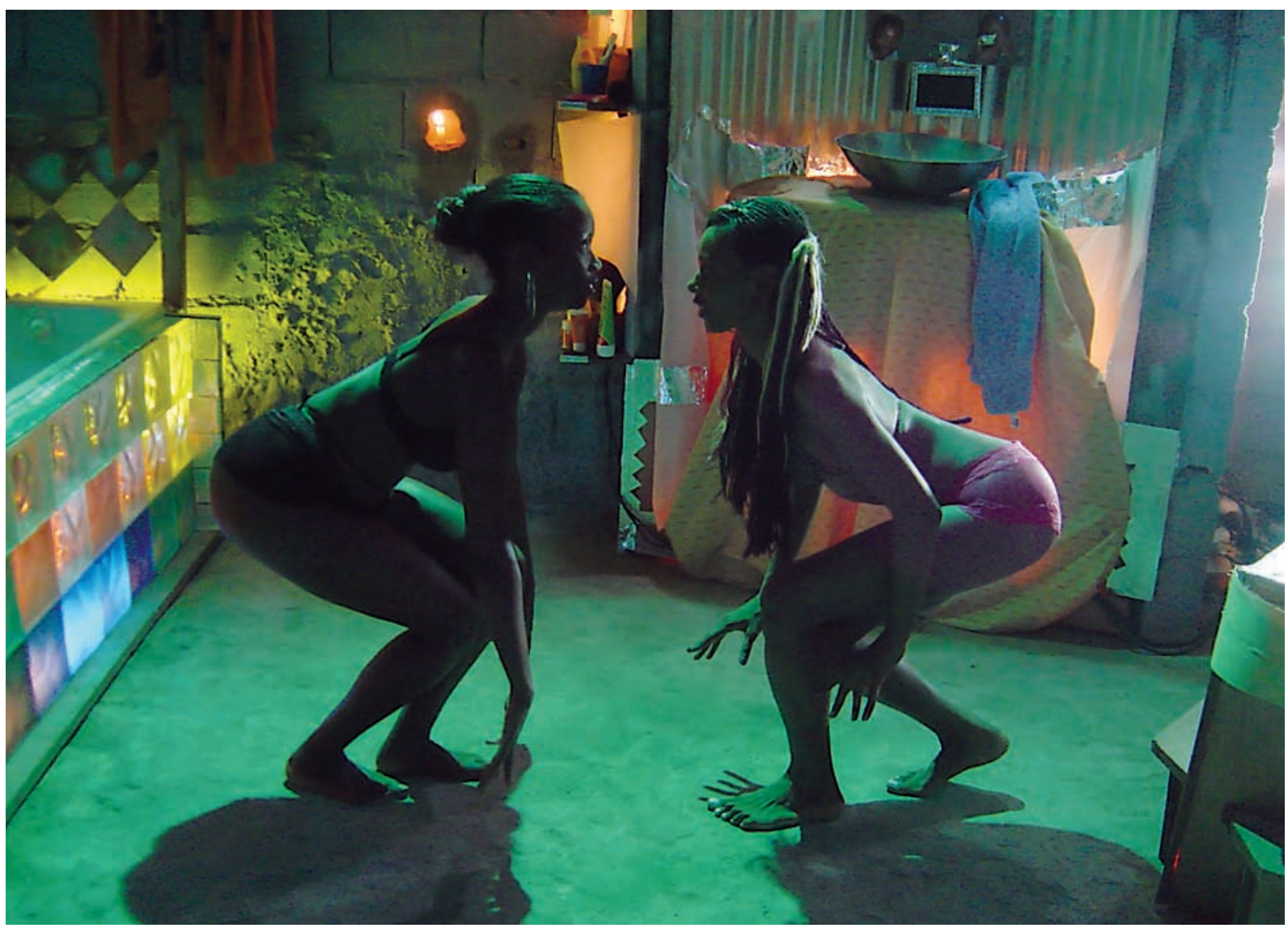

Les saignantes, 2006. Film still. Courtesy the filmmaker

yet paradoxically, "the country now had a chance to escape from the darkness." Mevungu both casts a spell on society and creates the conditions for social change.

One ambivalent depiction of mevungu in Les saignantes is the extravagant funeral. Mourning has become banal in this future Cameroon. The most exclusive parties in the country are "Deuils de Grands Personalités” (Wakes for Important Per- illusory phantasm that prevents the greater population from realizing the absurdity of their celebration of death. Mevungu somehow occludes the population's critical self-consciousness, thereby creating a sort of Marxian false consciousness that must be overcome. From this viewpoint, mevungu can be understood as a part of the structure that bears down on social actors, challenging their putative agency and their ability to engage in critical thought. 
The paradox of mevungu's effect on death celebrations is evident when Majolie has an epiphany while attending a celebrity wake. She realizes that she and Chouchou can use mevungu to achieve their aim of material wealth and end their practice of prostitution. In this moment, they decide to prepare the SGCC's corpse and use his wake to facilitate their agenda. The film's narrator then extends this use of mevungu to all of society: "It was actually mevungu that everyone in this country needed." Here mevungu somehow becomes an entity to be possessed and manipulated to one's advantage. Rather than a form of structural constraint, here mevengu is a vehicle through which to escape such constraint.

Another instance in which mevungu simultaneously inhibits and instigates social action is the final scene of the film, where Majolie and Chouchou physically fight the minister of state. On this occasion, mevungu's conflicting characteristics are represented in the body itself, not the larger society. Majolie and Chouchou initiate the fight by confronting the minister as he attempts to rape another woman. The two young women first strike blows to his torso and head, but they quickly resort to mevungu. As the minister repeatedly charges toward them, Majolie and Chouchou raise their hands, and a gold-colored dust emerges from the palms of their hands and moves toward the minister in slow motion, knocking him to the ground. Between each of the minister's charges, they (somewhat absurdly) dance in choreographed movements until the minister finally lies on the ground unconscious. In this instance, mevungu acts like a resistant or even autoimmune force that emerges from the body. Mevungu provides Majolie and Chouchou with a palpable sense of agency by helping them defeat the minister without actually touching him.

The flip side of this bodily agency is mevungu's inhibiting, almost toxic effect on the body. When the fight is over and the minister lies motionless, Majolie and Chouchou are forced to rid their bodies of mevungu: "Maybe we neutralized it, but the beast was still alive. Mevungu was something . . . that would either destroy us or destroy the country. We had to get rid of mevungu quickly if we wanted to stay alive." As the narrator explains that mevungu will destroy them, Majolie and Chouchou's bodies begin to violently convulse, as if mevungu is some sort of pathogen that must be released from the body. The same supernatural force that only moments earlier facilitated their effort to defeat the minister is now a force that threatens to kill them.

Between this bodily presence of mevungu and its societal presence in the extravagant funerals, the narrator's discursive articulations of the ancient rite are perpetually ambivalent. Throughout Bekolo's cyborgian articulations mevungu oscillates between its two functions: as structural threat and as conduit for liberation. However, mevungu is consistently depicted in the presence of the two young prostitutes, Majolie and Chouchou. Youth are the subjects around whom Bekolo constructs his ambivalent and often contradictory postmodern mevungu. Bekolo has clearly established a connection between young people and the cyborgian urgency of dismantling the monolithic meanings of African traditions and myths. For Bekolo, it is absolutely critical that youth think beyond the rigid narratives and significances of tradition. In his cyborgian politics, young people are the ones who must queer the singularity of traditional thought. In this instance, to think queer is to think cyborgian - to disrupt the logic and singular code of the culturally "organic" narrative.

As a part of his effort to unsettle the "one code that translates all meaning perfectly," Bekolo exhibits another central feature of cyborgian thought: a rejection of binary oppositions. "Certain dualisms [have been] systemic to the logics and practices of domination of women, people of colour, nature, workers, animals - in short the domination of all constituted as others." ${ }^{12}$ In cyborgian thought, dichotomies such as "culture/nature," "mind/body," and "truth/illusion" are understood as rigid constructs designed to explain the submission and domination of those considered aberrant or other. Through his challenge to the singularity of mevungu, Bekolo implicitly presses viewers to consider a possible breakdown of two particular dichotomies. The first is the "agent/structure" binary. The radical ambivalence of Bekolo's cyborgian mevungu threatens to throw these two designations into obsolescence. The filmmaker manipulates mevungu into an entity that is a part of the structure that shapes and constrains the lives of individuals; simultaneously, his mevungu enables his subjects to combat struc- 


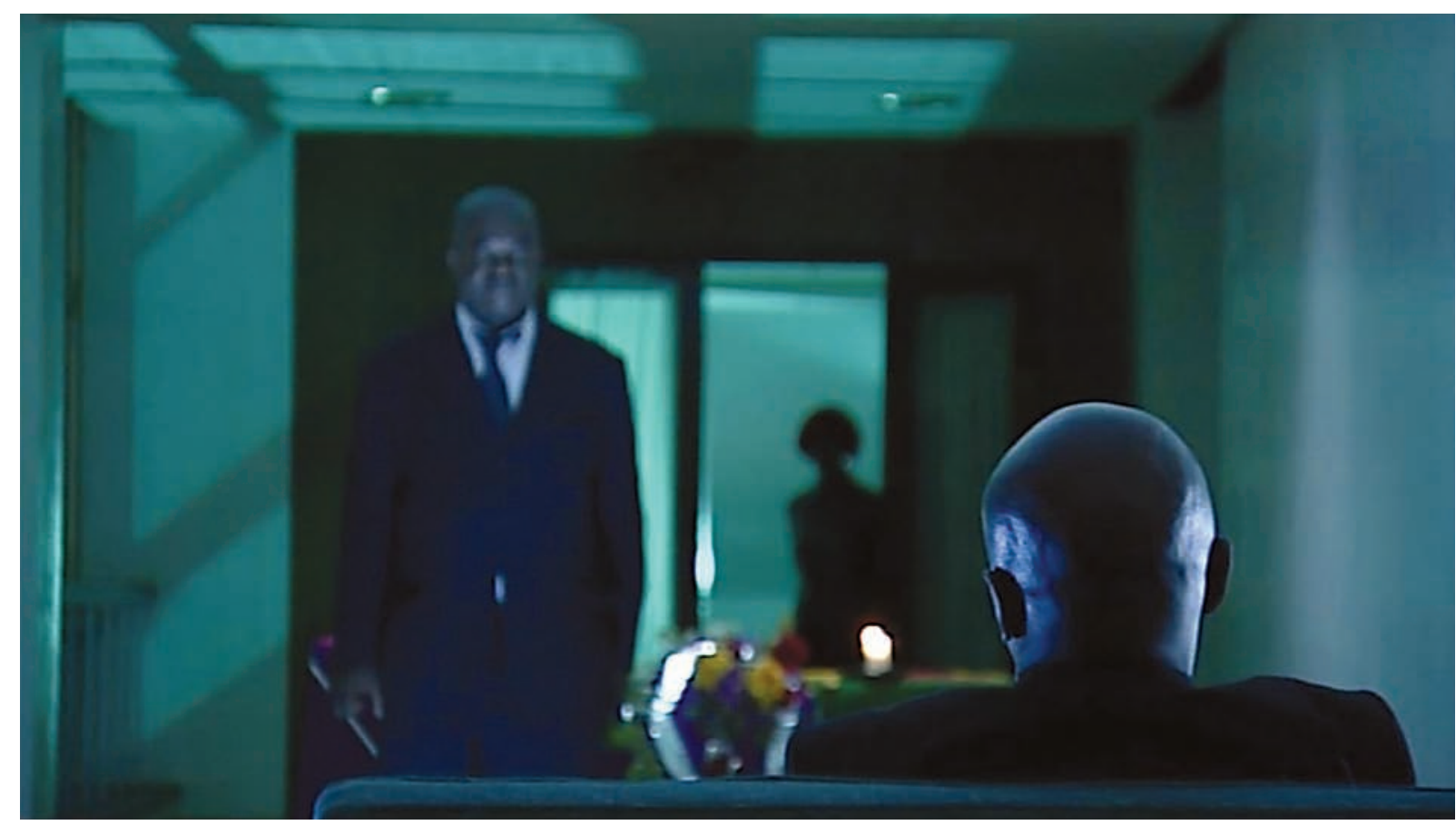

Les saignantes, 2006. Film still. Courtesy the filmmaker

tural constraints (e.g., corruption, masculinist state power). We might therefore say that Bekolo merges agent and structure into one entity - a single force that concurrently inhibits and empowers lives.

However, Bekolo's collapse of the agent/structure polarity may render both null and void. From this viewpoint, Bekolo challenges us to think something that previously - prior to his articulation - may have been unfathomable: that neither the agent nor the structure actually exists and that our cyborgian world demands a radically new theory of social action. From this vantage point, mevungu is selfnegating, since the agent and the structure exist in a single entity. The one cancels out the other, leaving us with an epistemological and perhaps ontological vacuum. In proposing this vacuum, Bekolo undercuts the "agent/structure" dualism and challenges us to question this particular binary's relation to the "logics and practices of domination." Have the terms agent and structure only rationalized the domination of the other? If, for instance, we regard the logic of late capitalism as the structure, and the subject of the postcolony as the agent, are these phrases merely an attempt to justify the subject's impoverishment and "underdevelopment"? Bekolo may not provide answers to these questions, but he takes the radical initial step of provoking them.

The second dualism that Bekolo breaks down with his cyborgian mevungu is the "traditional/ (post)modern" binary. In his scattered citations of mevungu, Bekolo loosely extracts pieces of LaburtheTolra's ethnographic account, such as the green slimy liquid and the mother of mevungu. Accompanying these "traditional" elements in Les saignantes are more "modern" elements, such as the massive martini glass holding the green slime and the instant mobile video technology that broadcasts the face of the mother of mevungu. In juxtaposing these elements of tradition and modernity, Bekolo effectively blurs the distinction between the two. His cyborgian thought challenges this rigid dichotomy that has perennially plagued African studies (among other disciplines). His blurring shatters the stereotypical connotations of tradition as timeless, culturally ossified, and primitive; he uproots the stereotype that African tradition includes only "authentic" oral traditions, wooden masks, and kente cloth. Similarly, Bekolo's breakdown of this polarity undercuts dominant notions that modernity is somehow synonymous with Euro-America; 
he challenges globally dominant systems of thought dictating that only the cultures, languages, technologies, and thought putatively originating in Europe or America can be deemed modern.

Bekolo's queering of the "traditional/modern" binary also seems to unsettle others, such as "civilized/primitive" and "developed/underdeveloped." In his African cyborgian world, such rigid designations only serve to subjugate the other, reinforcing the hegemonic systems of thought that have cast millions into apparent ontological irrelevance. Such dichotomies have labeled several Central African ethnic groups "pygmies," for instance, in an effort to dismiss them as uncivilized, aberrant, and primitive. Such dualisms no longer carry any relevance in Bekolo's cyborgian world.

Bekolo's dismantling of rigid dichotomies and monolithic narratives of African tradition centers on contingency. His aim is not to offer viewers a "new" mode of thought to substitute for the "old." Instead, he calls for us to be open to narrative and philosophical uncertainty - to a politics and thought "without guarantees." ${ }^{13}$ If we rely too much on fixed meanings and notions of authenticity and cultural determinism, then our thought becomes confined to what we have always known. Disrupting singular meanings turns a single code of thought into a polyvalent web of intellectual, and therefore social, potentiality. Emblematic of this polyvalent intellectual web is Les saignantes's narrative of two transgressive cyborgs who redefine notions of body and machine in their effort to subvert masculinist state power. Majolie and Chouchou are the African youth cyborgs who embody the role of the subject in Bekolo's postmodern vision.

\section{African Cyborgs, Oppositional Bodies}

Bekolo's structuring of Les saignantes around two female prostitutes effectively foregrounds issues of gender and sexuality. More precisely, his depiction of these two female cyborgs directly addresses how heteromasculinity configures systems of power and thought in society. In poststructuralist criticism, "phallogocentrism" is the privileging of masculinity in discourse and thought. ${ }^{14}$ It is the formation of power around a central symbol (i.e., the phallus) with the intention of fragmenting and controlling society. In short, the term implies a system of masculin- ist domination. Similarly, Achille Mbembe argues that colonial and postcolonial African societies are undergirded by what he calls "phallic domination." "The phallus has been the focus of ways of constructing masculinity and power," writes Mbembe. "Male domination derives in large measure from the power and the spectacle of the phallus ... from the individual male's ability to demonstrate his virility at the expense of a woman and to obtain its validation from the subjugated woman herself." ${ }^{15}$ Power in the postcolony centers on the male's need to constitute his masculinity in relation to female subordination. In other words, the male is man only when the female is other or subordinate.

The power structure in Les saignantes closely resembles the system of phallic domination that Mbembe describes. As prostitutes, Majolie and Chouchou are constantly at odds with the male government officials who seek them out as sex objects. These men seem to feel powerful and confident only when they possess these women sexually or when they denigrate women's efforts to challenge their authority. In short, the male identity in Bekolo's film is constituted vis-à-vis the subordination of women. However, this masculinist political landscape is the site of Bekolo's cyborgian intervention: the filmmaker depicts how body and machine might converge to subvert the phallic political structure.

An equally important part of the cyborgian feminist stance is the implicit rejection of notions of the organic female body and of the assumption that femininity, motherhood, and domesticity are synonymous. As Bekolo's cyborgian youth subjects, Majolie and Chouchou demonstrate how the female body can be regarded as the locus of transgressive power in the postcolony. The two women intend to use their cyborg bodies to break society's masculinist systems of thought, which subjugate women and confine them to rigid functions and gender identities.

In “A Cyborg Manifesto," Haraway writes: “Our bodies, ourselves; bodies are maps of power and identity. Cyborgs are no exception." The body is privileged in Haraway's radical politics - particularly the cyborgian body, whose most salient feature is its mergence with machine: "Intense pleasure in skill, machine skill, ceases to be a sin, but an act of embodiment [for the cyborg]. The machine is us." ${ }^{16}$ 
In the cyborg world, the female body is recrafted as a direct threat to phallogocentrism. Machines, modes of communication, and technologies converge in the cyborg's body in an effort to foster new social relations among women and new modes of thought that undermine hegemonic ideology.

If recrafting the female body by merging body and technology is central to the politics of the cyborg, Majolie and Chouchou are excellent models. The entire sex act that they perform for their corrupt government clients is built on this key cyborgian notion. While the client lies in bed, they attach themselves to a harness suspended from the ceiling and proceed with a midair spectacle of foreplay. While in the harness, the young women stretch out their arms and place their hands together in the gesture of a gun pointed at the client. Here machines and intimations of machines become indistinguishable from the body itself. Pleasure in machines merges with pleasure in sex and foreplay. This multivalent pleasure also fuses with intimations of violence. In Bekolo's depictions, we do not know where sexual gratification ends and transgressive violence begins.

We are first introduced to Majolie's machinesupported midair acrobatics in the film's prelude. Repetitive electronic keyboard music with occasional chanting voices drones throughout the brief scene. Through the stuttering camera cutaways and interspersed moments in slow motion, we see that Majolie is strapped to a harness attached to the ceiling, hovering over an old man. With a fierce grimace, she stretches out her arms and places her hands in the shape of a pistol while violently thrusting her pelvis. She throws off his eagerly groping hands. When she does permit him to touch, she convulses her body vigorously, then lifts herself back into the air. The machine-made of ropes, metal clasps, and a wooden rod - allows the body to float and move in ways that it could not accomplish alone. Majolie plays with and manipulates the man's desire for her body, refusing to relinquish her dominance. Her clear enjoyment of the harness device blurs with her intense pleasure in sexually teasing the man. Majolie continues with her teasing and gestural violence until suddenly the man dies of cardiac arrest. Shocked, Majolie opens his wallet to discover that he is the SGCC, one of the nation's most powerful officials. Majolie's body - in its mergence with machine and technology - has killed this grand homme. In a single moment, her symbolic violence has been transformed into literal violence.

The absence of dialogue, plot context, and spatial orientation makes this opening sequence inscrutable. However, as the film unfolds, we begin to understand its cyborgian significance. One scene in particular further elucidates the transgressive nature of the prostitutes' acrobatics. When Chouchou meets with Majolie to discuss the SGCC's death, Majolie reveals that she was enacting the position $d u$ tir, or the "shooting position," when the man died. Majolie re-creates the scene by erotically bending over in her underwear and raising her arms in the gesture of a gun. She thrusts her pelvis back and forth and jumps onto the harness. She flips several times in the harness, then hovers several feet over the ground in an exaggerated flying "superwoman" pose. Initially, it is clear that Majolie is demonstrating how she performed the position $d u$ tir on the SGCC. However, Chouchou soon joins in, and the two begin to thrust their pelvises and raise their gestured pistols in a meticulously synchronized manner, as if they were practicing their moves and refining their skills. If in the prelude it was unclear whether Majolie's movements were deliberately calculated and executed, the synchronization in this scene, the precision and mechanization of the women's movements, seems to clarify the element of intention or calculation. These notions of mechanization and calculation become even more relevant when applied to the mechanism (harness) that suspends them in midair and the gestured machine (gun) that they form with their hands. Their cyborgian bodies have undergone a process of mechanization - refining, crafting, and welding the body with precision.

Intermittently throughout this scene, the frame momentarily shifts to a close-up shot of the minister of state staring directly into the camera, attempting to contact the SGCC on his videophone. The culmination of these rapidly fluctuating images - the prostitutes' position $d u$ tir and the infuriated gaze of the minister - creates a sort of disjointed antagonism. The minister's image feels at once like a form of ubiquitous surveillance of the women and like an 
unequivocal sadomasochistic gaze, yet the close-up image also hints that the minister may be the next victim of the women's gestural violence. The critical cyborgian feature of ubiquitous technology surfaces in this implied two-way video stream, though the precise role of the technology remains indeterminate, in keeping with the film's overall opacity.

The other side of this scene's implicit antagonism is Majolie and Chouchou's position $d u$ tir. Revealing the symbolic import of this position and portending the events to come, the omniscient narrator states, "On aiguisait notre arme" (We sharpened our weapon). The narrator's laconic articulation significantly augments the symbolic violence of the gesture and reaffirms that the "weapon" is being prepared with particular adversaries in mind. With their explicit symbolic violence, Majolie and Chouchou subvert the dominance of their corrupt clients. The reenactment of the position $d u$ tir and preparation of their "weapon" in this scene represents their returning of the minister's violent gaze, as it were. Given the clear phallic shape of their hand-pistol, the position $d u$ tir can be seen as their reciprocation of the violent state phallus.

Reading the minister's invasive gaze, we can see that the hegemony of the state phallus threatens to condition and control the lives of Majolie and Chouchou. Drawing again from Mbembe's notion of phallic dominance in the postcolony, we might even say that the state's phallus is what structures society and structures these women's subjugated roles as mere holes for the state's phallic pleasure. The radical sexual politics of Majolie and Chouchou centers on their knowledge of society's phallogocentric structure and modes of thought and, in turn, their ability to anticipate and manipulate that structure from within. By continuing to play the role that is expected of them, luring officials with their raw sexuality, their transgression remains muted until the final sequence of the film. Chaos ensues when Majolie ultimately refuses the minister's demand for intercourse. ${ }^{17}$ All of Majolie's sexually suggestive

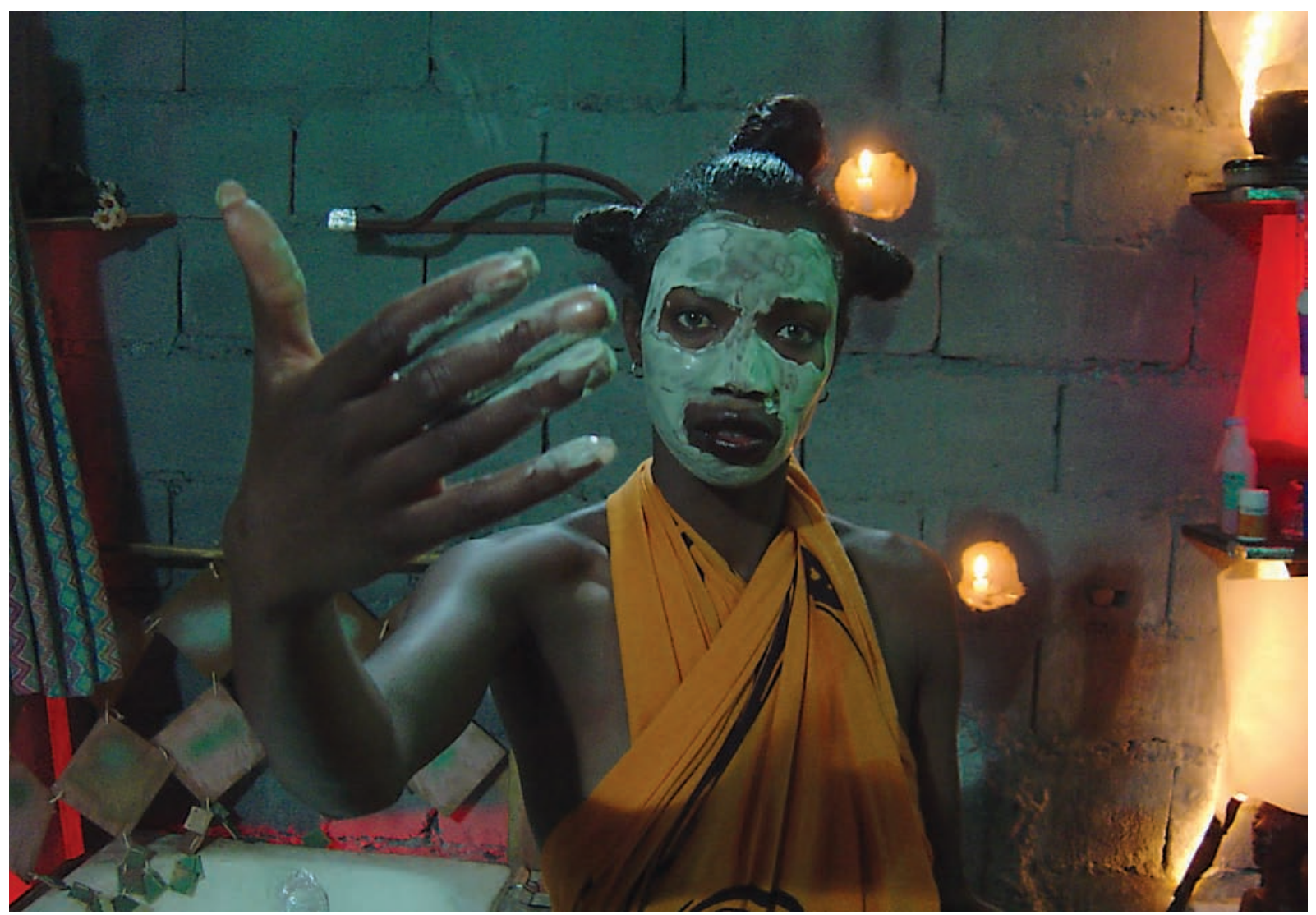

Les saignantes, 2006. Film still. Courtesy the filmmaker 
movements and behavior culminate in this denial of the phallus. With the disavowal comes the cyborg's symbolic rejection of the phallus's privileged place and function in society. Through their mechanized cyborg bodies, Majolie and Chouchou symbolically refuse the physical, spatial, and intellectual dominance that the masculinist state has imposed.

Related to the cyborgian youth's repudiation of masculinist power is her repudiation of dominant notions of the organic female body. The cyborg feels no connection to "Western" myths of the female body originating in some primal Garden of Eden. Haraway describes the normative concept thus: “Up till now ... female embodiment seemed to be given, organic, necessary; and female embodiment seemed to mean skill in mothering and its metaphoric extensions." 18 Cyborgian thought argues against "organic" and "holistic" politics, which calls for metaphors of rebirth and reproductive sex. Indeed, cyborgs are "suspicious of the reproduction matrix and of most birthing." 19

The cyborgs in Les saignantes enact such refusals of imposed female identity. They renounce notions of organicism and purity through their intense pleasure in machines and intimations of machines and in sexually teasing their clients. Their skill and self-confidence come not from notions of motherhood and the organic family but from their ability to manipulate their clients and invent new ways of undermining masculinist power. At no point in Les saignantes do Majolie and Chouchou speak of the need to be with a man, get married, or have children. The two are in their late youth (presumably mid- to late twenties), a time when perhaps there are social expectations that they will find a man, settle down, and start a family. But these young women have no interest in being defined in relation to the opposite sex. They have sex for work and pleasure - not reproduction. The cyborg needs social bonds to sustain life, but not the conventional bonds, which relegate women to a secondary or behind-the-scenes role. Majolie and Chouchou refuse to be confined to the thought and power structures that center on phallic domination. The other will not define them; they will define themselves.

While the oppositional cyborgs in Les saignantes have shown how the holes in masculinist thought can be picked apart, a critical question remains: if the cyborg is suspicious of reproduction and rebirth, then how might we imagine the continuation of cyborg life? Haraway argues for "regeneration," not "rebirth." She explains that when a salamander becomes injured and loses a limb, it undergoes a "regrowth" of the structure and a "restoration of function." "The regrown limb can be monstrous, duplicated, potent." ${ }^{20}$ The point here is not to think of Haraway's "regeneration" in a strictly literal or metaphorical sense, though both are certainly possible. It is simply to think past what we have always thought and known.

Although questions of reproduction and regeneration may go unanswered in Bekolo's film, there must be an African cyborgian way of thinking beyond our limited conception of the continuation of life. In the cyborgian tradition, as it were, perhaps one way might involve a combination of mevungu, test tubes, and sperm banks that revolutionize microfinance in sub-Saharan Africa. Grassroots capitalists, laboratory biologists, and mothers of mevungu converging in Yaoundé, Kinshasa, and Dakar - pushing cognitive limits, regenerating bodies, and prolonging life. These thoughts are not far removed from Bekolo's cyborgian thought. After all, he himself has identified immortality as "our greatest human project." 21

\section{Breaking the Limits of Thought}

Contemplating Bekolo's vision of immortality necessitates that we take into account the blurring of fiction and reality that his thought presupposes. He calls for "lifting the barrier between the real and the imaginary and redefining the rules of a new space... where we can live our brave, new invented story."22 This lifting of the barrier separating our supposed lived experience and imagination forecloses a strictly praxis-oriented reading of his vision. His vision straddles the line between direct political action and discursive philosophy. It is this potential for polyvalence that enables Bekolo's cyborgian vision to resonate on the level of thought. Multiple layers of meaning necessitate that we think through his text and open ourselves to new ways of thinking and imagining our social spaces.

Bekolo has directed his ambivalent postmodern thought at African youth because he believes they must intellectually remain open to reimagining and 
reconfiguring the social and epistemological world around them. For Bekolo, the question of youth is integrally linked to the question of futurity. To privilege Africa's young people is to privilege the continent's future. Youth will live to experience the African future; they must therefore be able to anticipate and shape the future of African thought.

In Bekolo's cyborgian effort to exaggerate African tropes of pathology, to reconfigure organic African tradition, and to present the transgressive acts of two young women, he undertakes a dual aesthetic and discursive approach to engaging youth audiences and provoking them to become critically aware of the modes of thought that condition them. Bekolo's film calls on them to question notions of commonsense thought, grand narratives, and negative stereotypes. To be sure, not all thought in society is necessarily hegemonic or masculinist. But if one does not question, one does not know what must be reimagined and reshaped. To be uncritical is to be intellectually stagnant, and if Africa's youth are intellectually stagnant, then the continent's future will be just as stagnant.

Perhaps the most ambiguous feature of Bekolo's cyborgian thought is its reception. It seems too early to tell how much his "new anatomy," "queered tradition," and hyperbolic representations will actually resonate among youth. If his vision remains unseen, then it will remain an insular fantasy. Youth must answer the call and dissipate the darkness that Bekolo so hyperbolically accentuates. Les saignantes is a vociferous scream. It is a call to thought that must now be pushed through.

\section{Matthew Omelsky is a doctoral student in English at} Duke University. He received his master's in Africana studies from Cornell University in 2011.

\section{Notes}

1. Jean-Pierre Bekolo, "Welcome to Applied Fiction," trans. Simon Burt, Journal of Cinema and Media 49, no. 2 (2008): 106-13.

2. A quintessential instance of Mambéty's experimental aesthetics is the opening sequence of Touki bouki, where Mambéty abruptly cuts between scenes of a tranquil cattle herding, a closeup shot of a cow being slaughtered, and a young man riding a motorcycle. See Touki bouki, DVD, directed by Djibril Diop Mambéty (1973; New York: Kino, 2005).
3. Frantz Fanon, The Wretched of the Earth, trans. Richard Philcox (New York: Grove, 2004), 239.

4. Les saignantes, DVD, directed by Jean-Pierre Bekolo (Quartier Mozart Films, 2006); Le complot d'Aristote, DVD, directed by Jean-Pierre Bekolo (JBA, 1996); Quartier Mozart, DVD, directed by Jean-Pierre Bekolo (California Newsreel, 1992). Unless otherwise noted, all translations from the French are my own.

5. Donna Haraway, “A Cyborg Manifesto: Science, Technology, and Socialist-Feminism in the Late Twentieth Century," in Simians, Cyborgs, and Women: The Reinvention of Nature (New York: Routledge, 1991), 151.

6. Ngugi wa Thiong'o, "The Language of African Literature," in Decolonizing the Mind: The Politics of Language in African Literature (Oxford: Currey, 1986), 4-33.

7. This scene seems to evoke the Nigerian dictator Sani Abacha's infamous death in 1998: he is said to have died in bed with a group of prostitutes.

8. Antonio Gramsci, Selections from the Prison Notebooks, trans. Quintin Hoare and Geoffrey Nowell-Smith (New York: International, 1971), 324-34; Stuart Hall et al., "Politics and Ideology: Gramsci," in On Ideology, ed. Stuart Hall et al. (London: Hutchinson, 1978), 45-71.

9. Haraway, "A Cyborg Manifesto," 176.

10. Olivier Barlet, "Entretien d'Olivier Barlet avec Jean-Pierre Bekolo à propos de Les saignantes: Être à la fois africain et contemporain," Africultures.com, July 2005, www.africultures.com/php /?nav=article\&no=3944.

11. Philippe Laburthe-Tolra, Initiations et sociétés secrètes au Cameroun: Les mystères de la nuit (Paris: Karthala, 1985), 327-35. 12. Haraway, "A Cyborg Manifesto," 177.

13. See Stuart Hall's notion of "determinacy without guaranteed closures": "The Problem of Ideology: Marxism without Guarantees," in Stuart Hall: Critical Dialogues in Cultural Studies, ed. David Morley and Kuan-Hsing Chen (New York: Routledge, 1996), 45.

14. Discussions of logocentrism, phallogocentrism, and "longing for a center" can be found in Jacques Derrida's Of Grammatology as well as Gayatri Spivak's preface to the text. See Jacques Derrida, Of Grammatology, trans. Gayatri Chakravorty Spivak (Baltimore: Johns Hopkins University Press, 1997), lxix, 11-12. See also Haraway's use of the term phallogocentrism in "A Cyborg Manifesto," 175-76.

15. Achille Mbembe, On the Postcolony (Berkeley: University of California Press, 2001), 13. This particular excerpt was added to the English translation from the French.

16. Haraway, “A Cyborg Manifesto," 180.

17. This disavowal is not unlike Homi Bhabha's discussion of the colonial subject's "refusal to satisfy the colonizer's narrative demand" ("Sly Civility," in The Location of Culture [New York: Routledge, 1994], 132-44).

18. Haraway, “A Cyborg Manifesto," 180.

19. Ibid., 181.

20. Ibid.

21. Bekolo, "Welcome to Applied Fiction," 109.

22. Ibid. Here Bekolo does not seem to use the "real" and the "imaginary" in the Lacanian sense (i.e., the orders of the Real, the Symbolic, and the Imaginary), but instead as more ambiguously defined terms referring to praxis or lived experience and what we think or imagine. 